\title{
$\mathrm{NMO}-\mathrm{DBr}$
}

\section{The Brazilian Neuromyelitis Optica Database System}

\author{
Marco A. Lana-Peixoto', Lívia Edwiges Talim?', \\ Alessandra C. Faria-Campos², Sérgio V.A. Campos², \\ Cristiane F. Rocha', Lucas A. Hanke², Natália Talim?', \\ Paulo Henrique Batista², Carolina R. Araujo', Rodrigo Kleinpaul', for the \\ Brazilian Committee for Treatment and Research in Multiple Sclerosis
}

\begin{abstract}
Objective: To present the Brazilian Neuromyelitis Optica Database System (NMO-DBr), a database system which collects, stores, retrieves, and analyzes information from patients with NMO and NMO-related disorders. Method: NMO-DBr uses Flux, a LIMS (Laboratory Information Management Systems) for data management. We used information from medical records of patients with NMO spectrum disorders, and NMO variants, the latter defined by the presence of neurological symptoms associated with typical lesions on brain magnetic resonance imaging (MRI) or aquaporin-4 antibody seropositivity. Results: $\mathrm{NMO}-\mathrm{DBr}$ contains data related to patient's identification, symptoms, associated conditions, index events, recurrences, family history, visual and spinal cord evaluation, disability, cerebrospinal fluid and blood tests, MRI, optic coherence tomography, diagnosis and treatment. It guarantees confidentiality, performs cross-checking and statistical analysis. Conclusion: $\mathrm{NMO}-\mathrm{DBr}$ is a tool which guides professionals to take the history, record and analyze information making medical practice more consistent and improving research in the area.
\end{abstract}

Key words: NMO-DBr, Brazilian Neuromyelitis Optica Database System, neuromyelitis optica, NMO variants, database.

\section{NMO-DBr: o banco de dados brasileiro em neuromielite óptica}

\section{RESUMO}

Objetivo: Apresentar o Brazilian Neuromyelitis Optica Database System (NMO-DBr), um sistema de banco de dados que coleta, arquiva, recupera e analisa informações de pacientes com neuromielite óptica (NMO) e doenças relacionadas. Método: NMO-DBr usa o sistema Flux, um LIMS (Laboratory Information Management Systems) para gerenciamento de informações. As informações foram colhidas dos prontuários de pacientes com espectro de $\mathrm{NMO}$ e variantes de NMO, estas últimas definidas por quadro neurológico associado a lesões encefálicas típicas à imagem pela ressonância magnética (IRM) ou à soropositividade do anticorpo anti-aquaporina-4. Resultados: NMO-DBr contém dados relativos a identificação, sintomas, condições associadas, eventos índices, recorrências, história familiar, avaliação visual e da medula, incapacidade, exames do líquor e de sangue, IRM, tomografia de coerência óptica (OCT), diagnóstico e tratamento. O sistema assegura confidencialidade, cruza dados e faz análises estatísticas. Conclusão:

\section{Correspondence}

Marco A. Lana-Peixoto

Rua Padre Rolim 769 / sala 1301

30130-090 Belo Horizonte MG - Brasil

E-mail:marco.lanapma@gmail.com

Received 20 June 2011. Accepted 27 June 2011.
NMO-DBr é uma ferramenta que possibilita a prática médica mais consistente e promove a pesquisa na área.

Palavras-chave: NMO-DBr, Brazilian Neuromyelitis Optica Database System, neuromielite óptica, variante de NMO, banco de dados.

${ }^{1}$ CIEM MS Research Center, Belo Horizonte MG, Brazil; ${ }^{2}$ Department of Computer Engineering, Federal University of Minas Gerais, Belo Horizonte MG, Brazil. 
Neuromyelitis optica (NMO) is an idiopathic inflammatory demyelinating disease of the central nervous system (CNS) most frequently characterized by recurring attacks of optic neuritis and myelitis. It can be distinguished from conventional multiple sclerosis (MS) on demographic, clinical, neuroimaging, cerebrospinal fluid (CSF) and serological grounds ${ }^{1,2}$.

The characterization of its immunohistopathology, strongly suggesting an autoantibody-mediated pathogenesis ${ }^{3}$, led to the search and identification of a specific autoantibody, the NMO-IgG ${ }^{4}$, and promptly, to the recognition of aquaporin-4 (AQP4) as the target antigen in the astrocytes foot processes at the blood brain barrier ${ }^{5}$. Since then, in the last few years, a massive amount of information has been published, deeply changing the understanding of the disease $\mathrm{e}^{6-14}$.

As AQP4 is ubiquitous in the CNS magnetic resonance imaging (MRI) of the brain reveals different types of lesions, some of them with unique patterns, in about 90\% of the NMO patients ${ }^{10,12-15}$. Although most of these lesions are asymptomatic, a variety of clinical manifestations may occur, either at the disease onset or during its course ${ }^{16-19}$.

In addition to the continued expansion of the concept of the disease, both on phenotypical and magnetic resonance imaging (MRI) grounds, the recent introduction of optic coherence tomography (OCT) to the investigation of the demyelinating diseases has provided significant information about the severity of damage to the retinal nerve fiber layer and macula distinguishing NMO from MS patients ${ }^{20}$.

As NMO spectrum disorders is highly prevalent among the demyelinating diseases of the CNS in Southeastern Brazil ${ }^{21}$ it is expected that a huge amount of information is available resulting in a better characterization of the disease. The need to manage such a large amount of data is a clear demand for the use of computational tools and a database to collect, store, retrieve, analyze, and ultimately employ in order to boosting research and improving medical care.

Herein we present the Brazilian Neuromyelitis Optica Database System (NMO-DBr), a specific database system which provides medical professionals with a tool to guide history taking, and record examination, disability scoring, as well as results of laboratory tests, MRI and OCT of patients with NMO and NMO-related disorders. The data are then conveniently analyzed, and get ready to be employed.

\section{METHOD}

\section{Source of data}

NMO-DBr was built at CIEM MS Research Center, Federal University of Minas Gerais Medical School, in Belo Horizonte. We used information from patients' his- tory, physical examination, (CSF) and laboratory workup, brain and spinal cord imaging, and OCT. All medical records contained signed Informed Consent by patients or next of kin. Local institutional Ethical Committee approval was secured.

All patients with diagnosis of NMO according to Wingerchuk's revised criteria ${ }^{2}$ and neuromyelitis optica spectrum disorders (NMOSD) ${ }^{6}$ were considered. Additional cases used to build the system included [1] patients with recurring or bilateral optic neuritis, or longitudinally extensive transverse myelitis (lesions extending over three or more vertebral segments), associated with brain lesions typical of neuromyelitis optica, (even if they were AQP4-antibody negative); [2] patients with no symptoms related to index events, but with at least two of the following: [i] posterior reversible encephalopathy syndrome (PRES), hypothalamic syndrome or brainstem syndrome; [ii] MRI brain lesions typical of neuromyelitis optica; [iii] AQP4-antibody seropositivity.

An index event was defined as a first attack of either optic neuritis, acute long transverse myelitis, or both simultaneously (within a time interval no longer than 30 days), with objective worsening of neurologic function, that lasted longer than 24 hours and that stabilized or eventually resolved either partially or completely. A recurrence was defined as the re-appearance of symptoms of a previous index event lasting longer than 24 hours, and separated by an interval longer than 30 days. Recurrences could also have partial or complete recovery. Fatigue alone and transient fever-related worsening of symptoms were not considered a relapse. Symptoms that occurred within a month after the initial symptoms of an attack were considered part of the same episode.

Visual function was evaluated and scored by using the Snellen Test Types and the Snellen's chart. Best vision was obtained with prescription glasses and pinhole occlude. Wingerchuk's Quantification of Optic Nerve and Spinal Cord Impairment was also used to score visual dysfunction in addition to motor, sensory and sphincter impairment individually ${ }^{2}$. General neurologic disability was evaluated by Kurtzke's Expanded Disability Status Scale (EDSS) ${ }^{22}$. Ocular fundus findings were recorded according to those recently described by Green and Cree. ${ }^{23}$. Brain and spinal cord MRI data included those considered as atypical for MS, and more consistently found in $\mathrm{NMO}^{10,12-15,24}$. Data derived from optic coherence tomography (OCT) were recorded as the average overall thickness of retinal nerve fiber layer (RNFL), the thickness of the RNFL for each retinal quadrant, and the macular volume and thickness ${ }^{20,25-27}$.

\section{The NMO-DBr computational system}

To manage data collection we used Laboratory In- 
formation Management Systems (LIMS). A LIMS is a complex computational system used to manage laboratory data with emphasis in quality assurance ${ }^{28,29}$. In this work we used the Flux LIMS, a workflow based system to implement a medical record system.Flux uses JAVA as programming language, the Web pages were JSP and the J2EE technology was used for code development. Flux is based on the SIGLa system ${ }^{30}$. Applets are used for the graphical interface. The database was developed with MySQL, a robust, scalable and free DBMS. To define a workflow, the Together Workflow Editor community edition was used with the XPDL standard. For managing the workflows Flux uses a specialized workflow manager. A workflow manager consists of a set of functions that controls the activities of a workflow. The workflow manager maintains a list of activities that have been executed, as well as the order of execution and the activities that are available for execution.

\section{RESULTS}

NMO-DBr consists of standardized forms, a database system and thw web-based interface. The system guarantees confidentiality through the use of passwords for system access as well as intellectual property for all participants through an approved NMO-DBr Code of Behavior. Relationship with third parties is also regulated by NMO-DBr regulations.

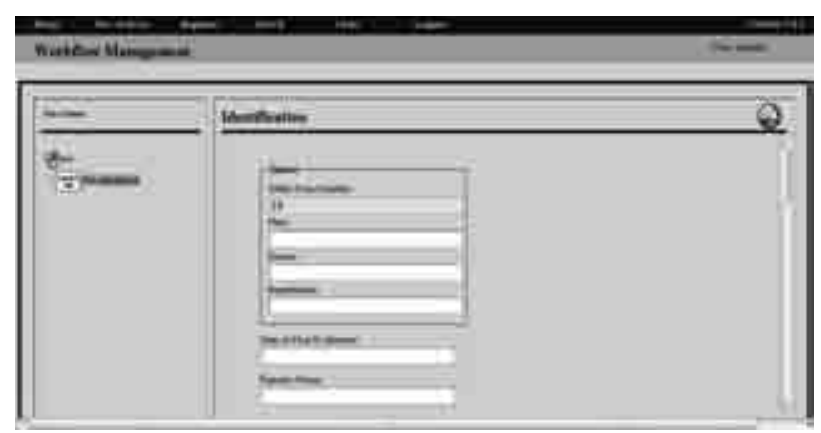

Fig 1. NMO-DBr software. Onset of registration of a new patient.

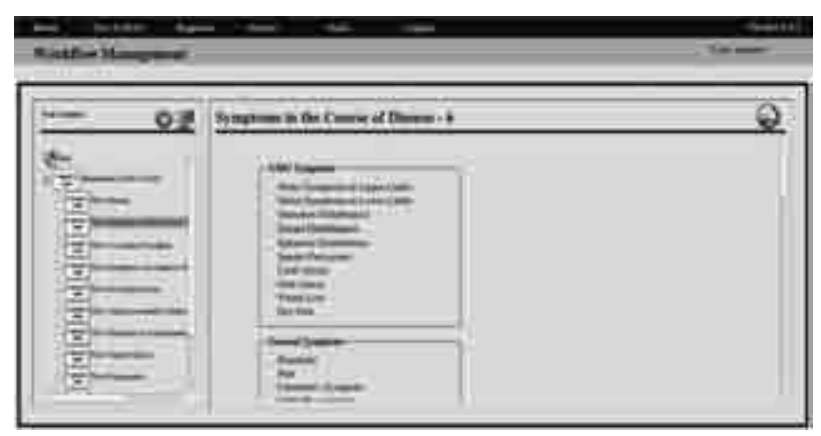

Fig 2. NMO-DBr software. List of symptoms in the course of the disease. The Tree on the left column indicates the task the system is currently executing.
The program contains items related to patients' registration and identification (Fig 1), demographic, clinical and disability status data, as well as the results of laboratory and imaging tests (Table 1).

$\mathrm{NMO}-\mathrm{DBr}$ shows a list of symptoms in the course of the disease (Fig 2). In addition to general symptoms the list contains symptoms related to involvement of the optic nerves and spinal cord, the cerebral cortex, corticospinal tract in its course from the frontal motor area through the posterior limb of the internal capsule and the cerebral peduncles, hypothalamus, brainstem and cerebellum (Table 2). The application conveniently displays the list in separate anatomic or functional compartments. This is followed by clinical characterization of the index events and recurrences regarding date, type of involvement (whether optic neuritis, myelitis or both simultaneously) and degree of recovery (Fig 3). NMO$\mathrm{DBr}$ also includes a dropdown list of endocrine and autoimmune disorders, identified in association with $\mathrm{NMO}$ (Table 3), and collects the Family history of autoimmunity as shown in Fig 4.

Recording of the visual acuity, the Kurtzke's Visual Functional System and the optic nerve function in the Wingerchuk's Scale of Optic Nerve and Spinal Cord Impairment is conducted by marking the corresponding visual acuity of each eye. That is easily performed in a dropdown Snellen visual acuity chart. Scores in the Wing-

Table 1. Basic components of the Brazilian Neuromyelitis Optica Database System (NMO-DBr).

- Patient's identification

- Symptoms in the course of disease

- Associated conditions

- Characterization of index events

- Recurrences

- Family history of autoimmunity

- Visual evaluation

- Spinal cord function evaluation

- Disability scoring

- Cerebrospinal fluid exam

- Laboratory work-up results

- Brain resonance imaging

- Spinal cord resonance imaging

- Optic coherence tomography results

- Diagnosis

- Treatment of attacks

- Prophylactic treatment 
Table 2. Possible symptoms in the course of neuromyelitis optica.

\begin{tabular}{|c|c|}
\hline Type & Related symptoms \\
\hline Optic nerve & $\begin{array}{l}\text { - Blurred vision } \\
\text { - Scotoma and loss of VF } \\
\text { - Optic disc edema or atrophy }\end{array}$ \\
\hline Spinal cord & $\begin{array}{l}\text { - Motor disturbances } \\
\text { - Sensory disturbances } \\
\text { - Sphincter/sexual disturbances }\end{array}$ \\
\hline $\begin{array}{l}\text { Posterior reversible } \\
\text { encephalopathy } \\
\text { syndrome }\end{array}$ & $\begin{array}{l}\text { - Impaired consciousness, } \\
\text { agitation, convulsion } \\
\text { - Visual disturbances } \\
\text { - Diplopia, nystagmus }\end{array}$ \\
\hline Hypothalamus & $\begin{array}{l}\text { - Hypothermia, fever } \\
\text { - Orthostatic hypotension } \\
\text { - Tachycardia } \\
\text { - Sleep disturbances } \\
\text { - Hyperphagia } \\
\text { - Endocrine disturbances }\end{array}$ \\
\hline Brainstem & $\begin{array}{l}\text { - Nausea, vomiting } \\
\text { - Diplopia, nystagmus } \\
\text { - Miosis } \\
\text { - Ptosis } \\
\text { - Facial pain or dysestesia } \\
\text { - Facial paralysis } \\
\text { - Hearing loss } \\
\text { - Vertigo and vestibular disturbances } \\
\text { - Ataxia }\end{array}$ \\
\hline General symptoms & $\begin{array}{l}\text { - Headache } \\
\text { - Pain } \\
\text { - Lhermitte's symptom } \\
\text { - Uhthoff's symptom } \\
\text { - Fatigue } \\
\text { - Memory disturbances } \\
\text { - Other cognitive disturbances } \\
\text { - Anxiety } \\
\text { - Depression }\end{array}$ \\
\hline Other symptoms & $\begin{array}{l}\text { - Painful spastic paroxysms } \\
\text { - Tremor } \\
\text { - Myoclonus } \\
\text { - Chorea } \\
\text { - Dyskinesia }\end{array}$ \\
\hline
\end{tabular}

erchuk's Scale for motor, sensory and sphincter impairment and Kurtzke's EDSS (Fig 5) are similarly recorded.

In addition to tests to rule out infectious myelopathies, results from the search of the following serum tests were recorded in the system: aquaporin- 4 antibody, thyroid peroxidase antibody (TPOAb); thyroglobulin antibody ( $\mathrm{TgAb}$ ); thyroid stimulating hormone receptor antibody (TRAb), lupus anticoagulant, anticardiolipin IgG antibody, anticardiolipin IgM antibody, ANA, Anti-Sm antibody, SSA and SSB antibodies, p-ANCA, c-ANCA, rheumatoid factor, acetylcholine-receptor antibody, antistriated muscle antibody, anti-MuSK antibody, total he-

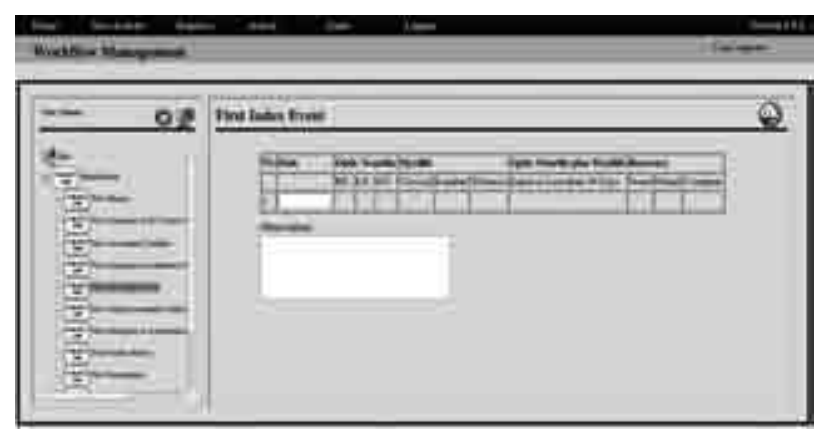

Fig 3. NMO-DBr software. Fields for the first index event with date, type and degree of recovery.

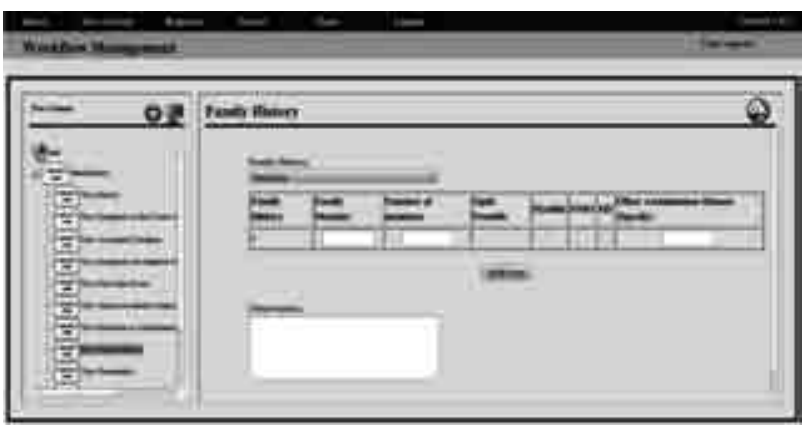

Fig 4. NMO-DBr software. Family history of autoimmunity.

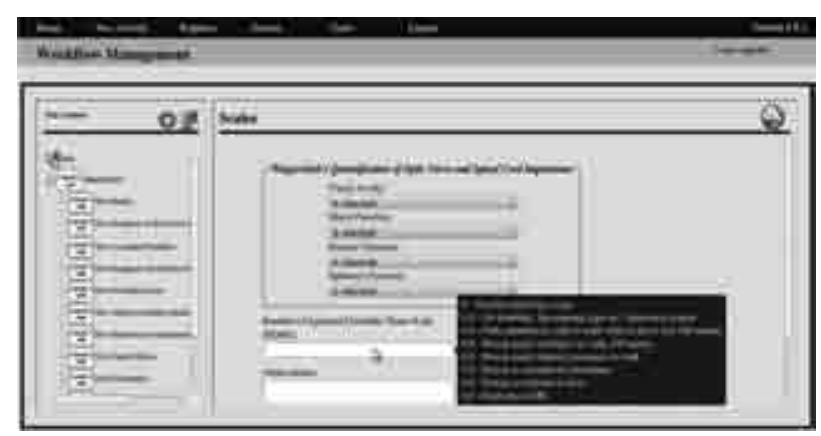

Fig 5. NMO-DBr software. Fields for collecting information on Wingerchuk's Quantification of Optic Nerve and Spinal Cord Impairment and Kurtzke's Expanded Disability Status Scale.

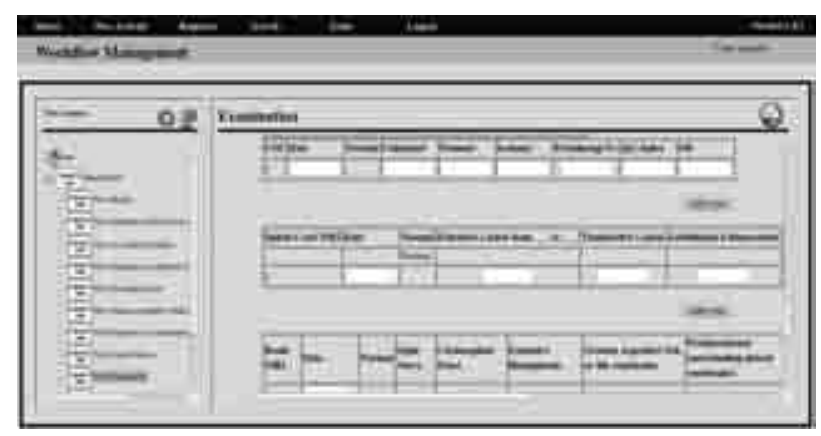

Fig 6. NMO-DBr software. Fields for results of cerebrospinal fluid analysis and findings of magnetic resonance imaging of the brain and spinal cord. 
Table 3. Endocrine and autoimmune disorders associated with neuromyelitis optica.

\begin{tabular}{|c|c|}
\hline \multirow{13}{*}{$\begin{array}{l}\text { Endocrine } \\
\text { disorders }\end{array}$} & • Hypophyseal adenoma \\
\hline & - Increased serum prolactin \\
\hline & - Galactorrhea \\
\hline & - Menstrual disorders \\
\hline & - Diabetes mellitus \\
\hline & - Hypothyroidism \\
\hline & - Hyperthyroidism \\
\hline & - Growth hormone disorders \\
\hline & - Hyperphagia \\
\hline & - Obesity \\
\hline & - Hyponatremia (Inappropriate ADH secretion) \\
\hline & - Decreased serum FSH \\
\hline & - Decreased serum LH \\
\hline \multirow{20}{*}{$\begin{array}{l}\text { Autoimmune } \\
\text { disorders }\end{array}$} & - Allergy \\
\hline & - Myasthenia gravis \\
\hline & - Hemolytic anemia \\
\hline & - Polyarteritis nodosa \\
\hline & - Polymyositis \\
\hline & - Rheumatoid arthritis \\
\hline & - Psoriasis \\
\hline & - Sclerosing cholangitis \\
\hline & - Thrombocytopenic purpura \\
\hline & - Behçet's disease \\
\hline & - Antiphospholipid syndrome \\
\hline & - Crohn's disease \\
\hline & • Sjögren's syndrome \\
\hline & • Hepatitis ( autoimmune) \\
\hline & - Vitiligo \\
\hline & $\cdot \operatorname{SLE}$ \\
\hline & - Hypothyroidism \\
\hline & • Hyperthyroidism \\
\hline & - Graves' disease \\
\hline & - Uveitis \\
\hline
\end{tabular}

molytic complement (CH50) and its fractions (C3 and C4), as well as vitamin B12, folate, methylmalonic acid, and homocysteine serum concentrations . Data on CSF included normal CSF, number of cells per cubic millimeter; number of neutrophils per cubic millimeter; number of eosinophils per cubic millimeter, concentration of protein $(\mathrm{mg} / \mathrm{dL})$, IgG index, and presence of oligoclonal bands outnumbering those of serum.

The section for collecting data on MRI contained the main findings we have observed in our cohort as well those so far reported by investigators in AQP-4 seropositive patients ${ }^{10,12-15,24}$. Figure 6 displays the fields for CSF and
MRI data on NMO-DBr. As the most common and typical findings are listed in the software the user has no difficulty looking for them on patients' individual exams. Data on thickness of the RNFL and macular volume and thickness are then collected in an equally user-friendly way.

In the diagnosis section $\mathrm{NMO}-\mathrm{DBr}$ takes into account the sensitivity variability of the AQP4 antibody assays $^{31-36}$ and the typical lesions which have been described on brain MRI ${ }^{10,12-15,24}$. In addition to choices within the widely accepted NMO spectrum disorders ${ }^{2,6}$ the system includes patients with formes frustres of NMO, typical lesions of NMO on brain MRI and AQP4antibody seronegativity; and those who have brainstem syndrome, hypothalamic syndrome, or symptoms of encephalopathy in association typical lesions of NMO on brain MRI or AQP4-antibody seropositivity. These latter diagnostic categories are named after NMO variants by NMO-DBr. A final diagnostic choice is Not NMO.

The NMO-DBr next section was specifically designed to collect data on management of acute attacks and relapse prevention. Treatment of attacks included oral prednisone, intravenous pulse of methylprednisolone, plasmapheresis, and IV immunoglobulin. For each coursed of treatment the degree of recovery is recorded. Approach to relapse prevention included the use of oral prednisone, azathioprine, rituximab, intravenous immunoglobulin, mitoxantrone, micophenolate mofetil and cyclophosphamide. Data for each of these therapeutic regimens is then recorded with its corresponding efficacy.

\section{DISCUSSION}

By using a specialized data management system we have been able to create a workflow to specify the NMO patients data format and implement the medical records system in a short amount of time. In this work we used the Flux LIMS, a workflow based system to implement a medical record system. Flux incorporates a workflow management system, making it possible to create and manage customized workflows. For each new application a workflow is defined with its activities, rules and procedures. During the execution, for each workflow created, the values of attributes defined in a workflow description file are stored in Flux's database, allowing them to be managed and retrieved upon request. These characteristics increase system's flexibility and extend its usability to include the needs of multiple types of conditions. The resulting NMO-DBr turned to be a fast, easy and friendly to use system. It provides data consistency through automated cross-checking; performs statistical analysis, and guarantees confidentiality for patients and investigators alike.

Recent advances in the immunopathogenesis of NMO have emphasized the deleterious effect of aqua- 
porin -4 antibody. The lesions are initiated by its binding to AQP-4 in any part of the brain parenchyma, activating complement, and then destroying astrocytes ${ }^{11}$. As AQP-4 is ubiquitous in the CNS, many different manifestations antedating or even in the absence of optic neuritis or myelitis may occur ${ }^{31-33}$. On the other hand, serum detection of anti-AQP4 antibody in NMO patients varies widely by different assays and in different populations ${ }^{34-36}$. Factors such as the use of corticosteroid or immunossupressant drugs may also interfere with the test sensitivity ${ }^{32}$.

NMO-DBr application takes into account these facts as it reckons data on neurologic symptoms antedating or not related to the classical NMO index events. The system, ultimately, allows to broaden the spectrum of the disease adding, among its formes frustres or NMO variants, patients who are anti-AQP4 antibody seronegative but, on the other hand, have typical NMO lesions on brain MRI in association with either just one of the index events, or with symptoms related to reversible encephalopathy, hypothalamus or brainstem syndrome.

The NMO-DBr system is a comprehensive and specific database to collect, store, retrieve, analyze and support research, ultimately improving medical care in the expanding field of NMO.

ACKNOWLEDGMENT - The authors would like to thanks Satya Sistemas for participating in this research by making the Flux System available and assisting in the development of the workflow.

\section{REFERENCES}

1. Wingerchuk DM, Hogancamp WF, O'Brien PC, Weinshenker BG. The clinical course of neuromyelitis optica (Devic's syndrome). Neurology 1999;53: 1107-1114.

2. Wingerchuk DM, Lennon VA, Pittock SJ, Lucchinetti CF, Weinshenker BG. Revised diagnostic criteria for neuromyelitis optica. Neurology 2006;66: 1485-1489.

3. Lucchinetti CF, Mandler RN, McGavern D, et al. A role for humoral mechanisms in the pathogenesis of Devic's neuromyelitis optica. Brain 2002;125: 1450-1461.

4. Lennon VA, Wingerchuk DM, Kryzer TJ, et al. A serum autoantibody marker of neuromyelitis optica: distinction from multiple sclerosis. Lancet 2004; 364:2106-2112.

5. Lennon VA, Kryzer TJ, Pittock SJ, Verkman AS, Hinson SR. IgG marker of optic-spinal multiple sclerosis binds to the aquaporin-4 water channel. J Exp Med 2005;202:473-477.

6. Wingerchuk DM, Lennon VA, Lucchinetti CF, Pittock SJ, Weinshenker BG. The spectrum of neuromyelitis optica. Lancet Neurol 2007;6: 805-815.

7. Lana-Peixoto MA. Devic's neuromyelitis optica: a critical review. Arq Neuropsiquiatr 2008;66:120-138.

8. Matà S, Lolli F. Neuromyelitis optica: An update. J Neurol Sci 2011;doi: 10.1016/j.jns.2011.01.002.

9. Bizzoco E, Lolli F, Repice AM, et al. Prevalence of neuromyelitis optica spectrum disorder and phenotype distribution. J Neurol 2009;256:1891-1898.

10. Ito S, Mori M, Makino T, Hayakawa S, Kuwabara S. 'Cloud-like enhancement' is a magnetic resonance imaging abnormality specific to neuromyelitis optica. Ann Neurol 2009;66: 425-428.

11. Saadoun S, Waters $P$, Bell AB, Vincent A, Verkman AS, Papadopoulos MC. Intra-cerebral injection of neuromyelitis optica immunoglobulin $\mathrm{G}$ and human complement produces neuromyelitis optica lesions in mice. Brain 2010;133:349-361.

12. Pittock SJ, Lennon VA, Krecke $K$, Wingerchuk DM, Luchinetti CF, Weinshenker BG. Brain abnormalities in neuromyelitis optica. Arch Neurol 2006; 63:390-396.

13. Pittock SJ, Weinshenker BG, Lucchinetti CF, Wingerchuk DM, Corboy JR, Lennon VA. Neuromyelitis optica brain lesions localized at sites of high aquaporin 4 expression. Arch Neurol 2006;63:964-968.

14. Nakamura M, Misu T, Fujihara K, et al. Occurrence of acute large and edematous callosal lesions in neuromyelitis optica. Mult Scler 2009;15:695-700.

15. Kim W, Park MS, Lee SH, et al. Characteristic brain magnetic resonance imaging abnormalities in central nervous system aquaporin-4 autoimmunity. Mult Scler 2010;16:1229-1236.

16. Chalumeau-Lemoine L, Chretien F, Larbi AGS, et al. Devic disease with brainstem lesion. Arch Neurol 2006;63:591-593.

17. Takahashi T, Miyazawa I, Misu T, et al. Intractable hiccup and nausea in neuromyelitis optica with aquaporin-4 antibody: a herald of acute exacerbations. J Neurol Neurosurg Psychiatry 2008;79:1075-1078.

18. Viegas S, Weir A, Esiri M, et al. Symptomatic, radiological and pathological involvement of the hypothalamus in neuromyelitis optica. J Neurol Neurosurg Psychiatry 2009;80:679-682.

19. Baba T, Nakashima I, Kanbayashi T, et al. Narcolepsy as an initial manifestation of neuromyelitis optica with anti-aquaporin-4 antibody. J Neurol 2009;256:287-288.

20. de Seze J, Blanc F, Jeanjean L, et al. Optical coherence tomography in neuromyelitis optica. Arch Neurol 2008;65:920-923.

21. Talim LE, Talim N, Couy M, et al. Relative frequency of demyelinating diseases in the State of Minas Gerais, Southeastern Brazil. Arq Neuropsiquiatr 2011;69 (Suppl 2):17.

22. Kurtzke JF. Rating neurologic impairment in multiple sclerosis: an Expanded Disability Status Scale (EDSS). Neurology 1983;33:1444-1452.

23. Green AJ, Cree BAC. Distinctive retinal neve fiber layer and vascular changes in neuromyelitis optica following optic neuritis. J Neurol Neurosurg Psychiatry 2009;80:1002-1005

24. Bichuetti DB, Rivero RL, Oliveira DM, et al. Neuromyelitis optica: brain abnormalities in a Brazilian cohort. Arq Neuropsiquiatr 2008;66:1-4.

25. Merle H, Olindo S, Donnio A, et al. Retinal peripapillary nerve fiber layer thickness in neuromyelitis optica. Invest Ophthalmol Vis Sci 2008;49: 4412-4417.

26. Ratchford JN, Quigg ME, Conger A, et al. Optical coherence tomography helps differentiate neuromyelitis optica and MS optic neuropathies. Neurology 2009;73:302-308

27. Naismith RT, Tutlam NT, Xu J, et al. Optical coherence tomography differs in neuromyelitis optica compared with multiple sclerosis. Neurology 2009;72:1077-1082.

28. Hinton MD. Laboratory Management Systems. Marcel Dekker, Inc. New York, 1995.

29. Quo C, WDW. Development of a Laboratory Information System forCancer Colaboration Projec ts. $27^{\text {th }}$ Annual International Conference of the Engineering in Medicine and Biology Society 2005;22:108-112.

30. Melo A, Faria-Campos A, DeLaat DM, Keller R, Abreu V, Campos S. SIGLa: an adaptable LIMS for multiple laboratories. BMC Genomics 2010;11 (Suppl 5):S8. doi:10.1186/1471-2164-11-S5-S8.

31. Sato D, Fujihara K. Neuromyelitis optica without typical opticospinal phenotype. Mult Scler 2010;16:1154-1155.

32. Fujihara K. Neuromyelitis optica and astrocytic damage in its pathogenesis. J Neurol Sci 2011;306:183-187.

33. Tanaka A, Yoshida T, Yamada T, et al. A case of cerebral aquaporinopathy. Mult Scler 2010;16:1252-1254.

34. Waters $P$, Jarius $S$, Littleton $E$, et al. Aquaporin-4 antibodies in neuromyelitis optica and longitudinally extensive transverse myelitis. Arch Neurol 2008;65:913-919.

35. Fazio R, Malosio ML, Lampasona $\mathrm{V}$, et al. Antiacquaporin 4 antibodies detection by different techniques in neuromyelitis optica patients. Mult Scler 2009;15:1153-1163.

36. Adoni T, Lino AM, Marchiori PE, Kok F, Callegaro D. Seroprevalence of NMO-IgG antibody in Brazilian patients with neuromyelitis optica. Arq Neuropsiquiatr 2008;66:295-297. 